\title{
Collaborative project-based learning approach to the enculturation of senior engineering students into professional engineer practice of teamwork
}

\section{Ms. Yu Xia, Pennsylvania State University}

Yu Xia is a doctoral candidate in Learning, Design, and Technology program in College of Education and research assistant in Leonhard Center for Enhancement of Engineering Education in College of Engineering at Penn State. She is currently doing research of collaborative learning in various learning contexts.

\section{Dr. Stephanie Cutler, Pennsylvania State University}

Stephanie Cutler has a Ph.D. in Engineering Education from Virginia Tech. Her dissertation explored faculty adoption of research-based instructional strategies in the statics classroom. Currently, Dr. Cutler works as an assessment and instructional support specialist with the Leonhard Center for the Enhancement of Engineering Education at Penn State. She aids in the educational assessment of faculty-led projects while also supporting instructors to improve their teaching in the classroom. Previously, Dr. Cutler worked as the research specialist with the Rothwell Center for Teaching and Learning Excellence Worldwide Campus (CTLE - W) for Embry-Riddle Aeronautical University.

\section{Prof. Dawn McFadden, Pennsylvania State University}

Since 2015, Dawn McFadden has been an Assistant Teaching Professor at The Pennsylvania State University. Her primary focus is the Chemical Engineering Capstone Design course and Chemical Process Safety and Control. She brings her over 20 years of experience in industry to the classroom to help the students connect their learning with real world application. While the focus of her career was in Research and Development (including several process patents), it also included assignments in production and capital deployment. 


\title{
Collaborative project-based learning approach to the enculturation of senior engineering students into professional engineer practice of teamwork
}

\author{
Yu Xia, The Pennsylvania State University \\ Dr. Stephanie Cutler, The Pennsylvania State University \\ Prof. Dawn McFadden, The Pennsylvania State University
}

\begin{abstract}
Working in teams is a vital component within the chemical engineering profession [1]. For senior chemical engineering students, the capstone design course provides an opportunity for students to work in teams to develop their teamwork skills in preparation for their future career. To better emphasize that necessary professional skills, especially teamwork, the Penn State Chemical Engineering capstone design course was redesigned for the 2017-2018 academic year. This paper aims to investigate student perceptions on their teamwork experiences during capstone design yielding insights to further scaffold students in the future. We conducted a questionnaire with both closed- and open-ended items. Descriptive statistics and qualitative coding helped investigate students' perception of the role of teamwork, themes from their reported teamwork experiences, and tensions between the themes. Given the conflicting perspectives on teamwork and problematic experience, conflict resolution strategies were absent from student responses, which we identify as a gap in the student's perceptions of teamwork. Thus, in moving forward, we recommend incorporating conflict resolution into curriculum as a critical part of teamwork.
\end{abstract}

\section{Introduction}

Working in teams is a vital component within the chemical engineering profession [1]. Solving complex real-world problems is often done by multidisciplinary groups of people. Collaborative competence is a critical skill for successful design teams. Good collaborative processes will allow members to feel psychological safety [2], to give constructive critiques, and to open up space for alternative and creative ideas. For senior chemical engineering students, the capstone design course provides a crucial opportunity for students to work in teams on longterm, synthesis-based projects to help develop their teamwork skills in preparation for their future career.

The inclusion of the teamwork skills in capstone courses at most engineering schools is a response to the ABET competencies for professional development that include teamwork, communication, data analysis, and problem solving [3]. According to the description of ABET's criterion, teams "consists of more than one person working toward a common goal and should include individuals of diverse backgrounds, skills, or perspectives" [4, p. 39]. Teamwork goes beyond the division of labor and the aggregation of individual tasks to result in the final product, but rather, it means a team who works as a whole towards a common goal and benefits from the diversity of its members. The capstone course for senior chemical engineering students is 
designed to be the culminating learning experience that connects the undergraduate learning to future work after graduation.

The Chemical Engineering capstone design course at our university was redesigned for the 2017-2018 academic year to further improve the learning experience and promote necessary professional skills, especially teamwork. This study aims to reveal the tensions/dissonance in students' perception of teamwork and its role in their future profession (or industry), in the semester-long capstone project, and in the actual collaborative processes. Ultimately, by examining these tensions, we aim to draw pedagogical implications for engineering education designed to promote the collaborative competence in future engineers, specifically within capstone design courses.

\section{Literature Review}

The inclusion of teamwork experience in undergraduate engineering programs is critical to student success for a few reasons. Firstly, there is a growing demand in organizations and industry for employees with strong teamwork competence since nowadays there is a high likelihood for employees to work in teams. Surveys conducted to reveal the recruiters' expectations for new employees often times show that recruiters are looking for teamwork and relevant skills such as communication and interpersonal skills [5]. The Job Outlook 2018 survey, conducted by the National Association of Colleges and Employers, found that the "ability to work in a team" was the highest rated (82.9\%) skill (along with "problem-solving skills") that recruiters are seeking in college graduates. As the economic environment is becoming increasingly complex and global, collaboration with different people, teams, departments, organizations, and industries is ever more commonplace. The demanding need for employees and managers to be able to work effectively in teams requires college programs develop this skill in undergraduates to meet the need.

Secondly, collaborative learning provides students with more complex learning environments and opportunities for them to develop sophisticated abilities in cognitive, metacognitive, socio-emotional aspects. That is, collaborative learning could help students develop competence by providing the learning opportunities that individual learning could not provide. In teamwork, when team members are engaged in negotiating shared meaning and constructing new problem-solving knowledge, they not only develop cognitive understanding of the content knowledge, but also metacognitive ability to understand, monitor, and regulate other members' learning, as well as socio-emotional ability to tackle possible conflicts resulted from possible miscommunication, different work habits, and other situations [6], [7].

Teamwork processes are complex with various factors playing consequential roles to the learning experience as well as the final results of teamwork. Prior research has studied team processes from different perspectives in the hope to understand the processes and further improve team performance, including team formation or team selection [8], team leadership [9], motivation [1], team conflict [10], [11], or comprehensive team effectiveness [5], [12].

Instead of focusing on one aspect of team performance, other works try to examine the factors associated with dysfunctional group performance and those associated with desired teamwork. An earlier work on the underperformance of a team [13] showed five factors: absence of trust, fear of conflict, lack of commitment, avoidance of accountability, inattention to results. These factors are interconnected. For example, when there is confidence and trust in other group members, it is less likely to avoid giving constructive critiques for the fear of 
conflict [13]. Also, if there is a difference between individual goal and the team goal and the members prioritizes the individual goal over team goal, this will negatively affect other aspects such as accountability and eventually the group results will suffer.

More recent work focuses on the desired behaviors that contribute to effective or highperformance teamwork [14]. The behaviors fall into five categories: contributing to the team's work; interacting with teammates; keeping the team on track; expecting quality; and having relevant knowledge, skills, and abilities [12], [14]. These factors point to the accountability, communication skills, commitment and co-regulation skills. A systematic review [15] into the psychology constructs researched in team effectiveness literature yields five constructs: social loafing, interdependence, conflict, trust, and shared mental models. Again, the social loafing reflects the importance of accountability to teamwork, interdependence and trust are interconnected, and conflict is critical because if they are managed well, they are sources for creativity and deepened understanding, but if not managed well, they negatively affect the whole team dynamics and hurt the psychological safety of the whole team. Team conflict has been correlated with other major factors, including team cohesiveness, psychological safety, and team experience, in which conflict feedback is negatively correlated with psychological safety [16].

Given the importance of teamwork experience to both the future professional career and the development of sophisticated abilities, engineering programs must provide targeted experiences to develop students' teamwork skills sufficiently. While it is true that most programs do require students to work in teams on their capstone projects [9], there is limited support provided for students prior or during the course to help students develop or improve specific teamwork skills [17]. The course redesign outlined in this paper highlights strategies used to help facilitate the teamwork required for the project as well as the student reaction to the overall teaming experience.

\section{Research goals and research questions}

While there is a wealth of research on team effectiveness, there is also a lack of research that focuses on the student perceptions of their experience and what they hold valuable or not in terms of the teamwork skills. Afterall, team effectiveness models should work better when students perceive it to be important and have a deep understanding of the various factors in those models, such as accountability, conflict management, trust, etc. This study extends the previous work on team effectiveness in engineering education by focusing on student perceptions of their teamwork experience, aiming to generate insights into future instructional support, including conflict resolution strategies, that could be provided for students to develop teamwork competence. As such, we conducted a longitudinal, convergent mixed methods study to answer the following research questions:

1. How do senior engineering students perceive the role of teamwork in capstone design projects and in future career?

2. What are the major themes senior engineering students report about their teamwork experiences in those capstone design projects?

3. What are the tensions between different aspects of collaboration that students have experienced? 


\section{Convergent mixed methods design}

\section{Methods}

Convergent mixed methods design $[18,19]$ is used for this study. Mixed methods research is defined as "research in which the investigator collects and analyzes data, integrates the findings, and draws inferences using both quantitative and qualitative approaches" by Tashakkori and Creswell [20]. Fetters, Curry, and Creswell [21] explicated how integration in mixed methods could happen at three levels: design, methods, interpretation and reporting. In convergent mixed methods design, quantitative and qualitative data collections are conducted concurrently but separately. The two strands of analysis and interpretation are then combined with particular attention to where they converge and diverge.

In this study, for the quantitative aspect, we collected rating scores on a 5-point Likert scale in terms of their overall course experience, skills to future relevance, what has helped them complete the course, and the suggested timing for each phase of the course (see Table 1). In the qualitative aspect, students' responses to open-ended questions were collected. In data analysis, we focused on teamwork to see consistencies as well as inconsistencies between the quantitative ratings and qualitative responses.

\section{Participants}

In the Fall of 2017, 46 students completed the Chemical Engineering Senior Design course. Of these students, 42 (91.3\%) participated in the survey offered during the final week of the semester that addressed students' experiences in the course through 3 sets of Likert scale questions and 5 open-ended questions. In the Spring of 2018, 178 students completed the Chemical Engineering Senior Design course. Of these students, 166 (93.3\%) participated in the updated survey with one more open-ended question. Altogether, we have 208 responses over the school year of 2017-2018.

\section{Capstone design course}

In this course, the teams were asked to create a plant design that minimizes capital and operating cost and maximizes profit, in a twelve-week design project for a chemical process addition to an existing plant using a Stage-Gate system of project management. In the Stage-Gate system, the final project is scaffolded so that a list of deliverables is given for each stage. At the end of each stage, the material is reviewed by the gatekeepers, in our case, industry mentors (more details on mentors below). The team is not permitted to proceed to the next stage until the gate (deliverables) meet gatekeeper expectations, potentially requiring revisions until concerns around the gate have been addressed and revised. For this project the stages were: Generate Options, Reduce Options, Model Process, Design Equipment, and Determine the Economics.

To better facilitate student teams' work on their project, class time consisted of one standard lecture per week and a two-hour block for active learning exercises, team meetings with the professor, and teamwork blocks. The teams were provided with a package of R\&D material providing information about the process (i.e. catalyst, reactions, special separations) and existing utilities and infrastructure available at the site.

The teams were required to submit executive update memos the week before each gate was due, submit their results after each stage, prepare a final presentation for a management audience and include an executive summary in their final report. Their grades were based on making reasonable assumptions, explaining design choices and correctly completing the design calculations. A pair of mentors from industry were assigned to provide coaching on the design 
process for each team. Each pair of mentors was assigned to two teams. That is, one team received coaching from two mentors. The mentors had weekly meetings with the teams and provided feedback on the gate submissions.

Students were grouped into four or five based on their test scores on a pre-test. If a student scored over $60 \%$ (received a passing score on the pre-test), they were permitted to choose one teammate. Otherwise the teams were based on test scores with the goal of encouraging peer mentoring [22]. To facilitate teamwork, students completed and submitted their Meyers-Briggs type including weight of each category with follow up discussions on how differences in personalities could make for positive or negative collaboration experience. Other activities to facilitate teamwork included a Code of Ethics co-written by teams, a signed list of participation for each member at each gate, and a teammate review for all team members at the end of the semester. The final review contributed to $5 \%$ of student final grade.

\section{Instrument and procedure}

The instruments were iteratively developed since 2016 fall semester, with the overall goal of receiving feedback from students to further improve the learning experience and meet student needs. In 2017 fall semester, the survey consisted of three sets of close-ended questions on 5point Likert scales, followed by four open-ended questions (see Table 1 in Appendix). In 2018 spring semester, we updated the survey, keeping the close-ended questions the same but made some changes to the open-ended questions (see updated questions in Table 1).

\section{Data analysis}

We first deleted the missing responses and duplicates. Descriptive statistical analysis was then conducted to see the average ratings and the standard deviations of each item, revealing the aspects that students held more important as compared to others. These statistical analyses helped us answer what role the students thought teamwork play in the capstone project and in their future careers.

In analyzing the open-ended responses, we adopted an iterative, open-ended coding process. We used the responses to the first two open-ended questions pertaining to teamwork. In the open-ended coding, we were looking for the aspects of teamwork as mentioned the responses, and students' attitudes and emotions as indicated in the wording. For example, in responses to the second question of "what is the importance of working on a team for this project", one response was "learn how to deal with people who don't care", which indicates that this student's team could have been challenging and run into difficulties, so we assigned the code "challenge" to this data point.

Also, the unit of analysis is one response. We did not split them into smaller utterances. Thus, multiple codes could be applied to one data point. For example, another response was "Working as a team is helpful for learning how much to contribute, and the expectations of others. The only problem is the team needs to be open to sharing how they feel with each other, which is not always the bond that a team creates." In this response, the student talked about individual responsibility as a group member ("how much to contribute") and communication ("open to sharing"), but also indicated possible challenges ("not always the bond that a team creates"). Thus, three codes apply to this response: challenge, communication, responsibility. The first and second authors discussed each code, the themes, and the data points that fell under the codes several times. Resulting codes are reported in the findings. The qualitative analyses 
helped to reveal how students understand teamwork, what they held critical to team effectiveness, and what they considered to be challenges.

Then, we put the quantitative and qualitative analyses together to answer the questions as to the contradictions in their conceptualizations of teamwork. However, we do not intend to say contradictions are negative, but rather, sources for challenges and opportunities for instructors to better support student's ability to work on teams.

\section{Findings}

RQ1: How do senior engineering students perceive the role of teamwork in capstone design projects and in future career?

To understand how students perceived the roles of teamwork in large, under-designed problem-solving projects and in their future career, we examined the student rating of "overall experience" and "skills relevant to future career". Both sets of rating questions included teamwork and thus we could see how students thought of teamwork as compared to other aspects included in the item sets.

As can be seen from Table 1 reporting the overall experience ratings, "Working on the capstone project as a team is a valuable experience" was rated the highest among the 19 statements, showing students recognition of importance and value of their teamwork experience. Also, "teamwork" was rated the highest among the six skills as listed when asked about the skills relevant to their future career (Table 2).

Table 1. average scores on the overall course experience ratings

\begin{tabular}{lcc}
\hline Statement & $\begin{array}{c}\text { Average } \\
\text { Rating }\end{array}$ & $\begin{array}{c}\text { Std. } \\
\text { Deviation }\end{array}$ \\
\hline My overall rating of the course is good. & 2.854 & 1.207 \\
The pace of the class is appropriate for my learning. & 3.043 & 1.252 \\
The 50-minute Monday lecture is helpful. & 2.762 & 1.291 \\
The 2-hour session is helpful. & 2.908 & 1.182 \\
The in-class assignments are useful. & 3.005 & 1.226 \\
The out-of-class readings are informative. & 3.137 & 1.259 \\
I review the readings before lecture each week. & 2.658 & 1.236 \\
Meeting with industry mentors is helpful. & 3.801 & 1.127 \\
The role of the industry process mentor in the capstone project is clear. & 3.360 & 1.325 \\
The grading for the course is clear. & 2.805 & 1.337 \\
The graduate TAs in this course help with my learning. & 2.630 & 1.235 \\
The undergraduate TIs in this course help with my learning. & 2.718 & 1.203 \\
The stage/gate setup of the project is useful. & 3.795 & 1.034 \\
I know the scope and intended audience of Status Memos. & 3.975 & .980 \\
I know the scope and intended audience of the Gate Assignments. & 4.091 & .802 \\
I know the scope and intended audience of the final Design Report. & 4.170 & .802 \\
I feel comfortable using the software needed in my capstone project. & 3.180 & 1.241 \\
The software needed in my capstone project is useful/important. & 3.801 & 1.074 \\
Working on the capstone project as a team is a valuable experience. & $\mathbf{4 . 1 8 8}$ & $\mathbf{1 . 0 4 4}$ \\
\hline
\end{tabular}


To further explore student perception on the role of teamwork, we conducted open coding on the student responses to the first open-ended question in 2018 Spring survey, which was "What are the most valuable topics/skills that you learned in this course?" In the 154 responses to this question, 7 categories of skills were mentioned repeatedly: teamwork and management skills $(\mathrm{n}=66,42.86 \%)$, design and modeling skills including equipment sizing $(\mathrm{n}=45,29.22 \%)$, software skills mainly in ASPEN ( $\mathrm{n}=41,26.62 \%)$, economic evaluation skills $(\mathrm{n}=37,24.03 \%)$, time management and project planning skills including organization and persistence $(\mathrm{n}=31$, $20.13 \%)$, communication skills including presentation and writing $(\mathrm{n}=29,18.83 \%)$, and problem solving skills $(n=21,13.64 \%)$. Since the focus of this paper is on teamwork, we will be focusing the results section on responses that mention teamwork. We provide this broader overview to aid the reader in seeing the other types of themes that were present.

Table 2. average scores on 6 skills in terms of relevance to their future work as professional Chemical Engineers

\begin{tabular}{lcc}
\hline Skills & Average Rating & Std. Deviation \\
\hline Writing & 4.191 & 0.901 \\
Teamwork & $\mathbf{4 . 5 8 7}$ & 0.736 \\
Using Modeling Software (e.g. Aspen+) & 3.105 & 1.292 \\
Solving an Under Defined Problem & 4.154 & 1.013 \\
Designing Equipment & 3.398 & 1.308 \\
Economic Evaluation & 3.633 & 1.231 \\
\hline
\end{tabular}

The open coding of responses to the question of "What additional skills would you like to practice through in-class activities?" yielded interesting results. In the 35 responses, four skills were mentioned repeatedly: sizing and equipment design skills (40.0\%), software skills (37.1\%), writing, presentation, and communication skills (14.3\%), and economic evaluation skills (11.4\%). Only one response stated, "Teamwork skills, The importance of communication, How to deal with team conflicts". That is, even though students recognized the value and relevance of teamwork in their ratings which had the highest averages scores, and nearly half students talked about teamwork as the most valuable skill learned, the majority did not think of teamwork as something they wanted to learn more about. To further explore this disconnect, we focused an indepth analysis on discovering how students understood "teamwork" and their teamwork experience in this course.

RQ2: What are the major themes senior engineering students report about their teamwork experiences in those capstone design projects?

To understand what stood out to students in their teamwork processes, we iteratively open-coded their responses to the question of "What is the importance of working on a team for this project?" The themes in student responses that reflected the importance of working on a team included team coordination, simulation to real world, necessity, and the challenges (see Table 3).

Team coordination included communication, individual responsibility, efficiency, strengths and weaknesses. Communication refers to instances where students talked about communication among group members to coordinate their group effort, how they need to have 
an open communication, keep in contact, catch up with everyone. This does not include the communication to deliver information as in presentations or writings. Taking individual responsibility or accountability is also deemed critical to teamwork, in which they thought team members should take equal amount of work and be held accountable for the delegated tasks. Teamwork is also considered beneficial to improve the work efficiency in completing a large project where a group of people would help with increasing the quality and reducing the time of the overall project. A last category that contributed to the overall team coordination was the strengths and weaknesses, where students talked about how to make the most of the strengths of team members to complete the project.

A second theme of teamwork was its simulation to real world work. Under this theme, the category of different perspectives refers to instances where students talked about how it was natural to have people with different perspectives, ideas, thoughts, styles, preferences, or cultural background if they work in groups in their future jobs. They also recognized the prevalence of group project in workplace in their field, as well as the importance of supporting each other when working on teams.

A third theme is necessity, where students expressed the impossibility of completing the project by one individual. And the fourth theme was the challenges that students reported to have run into during the collaboration process. Adding the code of challenges helped to reveal the conflicts or dilemmas inherent to those critical aspects of teamwork.

RQ3: What are the tensions in different aspects of collaboration that students have experienced?

To explore the tensions in the process of working in teams, we analyzed the challenges as indicated in student responses. From Table 3, we can see that 35 responses brought up challenges or some potential problems of teamwork. To further explore student understanding in the conflicts or dilemmas in teamwork, we analyzed the 35 responses in the category of challenges and see how they overlapped with other categories, which reflects the differences between and within individuals in how they approach the team collaboration. What was considered challenging under the necessity of working in teams was the sheer workload of the project. What was challenging in terms of individual responsibility was when some group members were reported to be not as productive as expected and it was difficult to hold team members accountable.

While some students thought they could benefit from the different perspectives among team members, some also reported challenges associated with working with different people, such as the potential disagreements, different working styles or personalities, expressing the desire to be able to choose their own teammates. Communication was considered to be critical to teamwork, but also a possible source for challenges because of the conflicting schedules and a lack of open atmosphere where they could safely share their thoughts. The challenges associated with real world work were also associated with other categories, such as different ideas or personalities, or conflicting schedules. Challenges associated with strengths and weaknesses overlapped with the individual responsibilities, where making use of the strengths of some team members meant that at the same time other team members were not taking a fair share of responsibility. Challenges with getting support were associated with the group size, which was commonly considered to be too big by the students. And challenges were talked about with improving efficiency and different ideas/perspectives at the same time. 
Table 3. The importance of working on a team for the capstone project

\begin{tabular}{|c|c|c|c|}
\hline Themes & Categories & Description/definition & Example \\
\hline \multirow{4}{*}{$\begin{array}{l}\text { Team } \\
\text { coordination } \\
(\mathbf{5 7 . 5 9 \% )}\end{array}$} & $\begin{array}{l}\text { Communication } \\
(38,20 \%)\end{array}$ & $\begin{array}{l}\text { When they directly mention communication among } \\
\text { their group members, or keeping in contact with each } \\
\text { other, keeping group members on the same page } \\
\text { through communication. Or when they talk about the } \\
\text { importance of having an open communication and of } \\
\text { sharing ideas. However, this category does not include } \\
\text { the cases when they mention communication with } \\
\text { professionals or mentors. }\end{array}$ & $\begin{array}{l}\text { I think that it teaches the } \\
\text { importance of } \\
\text { communication. If my team } \\
\text { mastered clear and direct } \\
\text { communication earlier, it } \\
\text { would have been easier at } \\
\text { the end. }\end{array}$ \\
\hline & $\begin{array}{l}\text { Responsibility } \\
(\mathbf{2 0}, 9.42 \%)\end{array}$ & $\begin{array}{l}\text { When students talk about the importance of assuming } \\
\text { responsibility for the group project; when they talk } \\
\text { about holding each other accountable, about how much } \\
\text { responsibility individual members should assume, } \\
\text { including how to take their own responsibility as part } \\
\text { of the group; when they talk about how the work } \\
\text { should be equally delegated, split, or divided work } \\
\text { among group members; when they talk about trusting } \\
\text { other group members that they will assume their } \\
\text { responsibilities. }\end{array}$ & $\begin{array}{l}\text { We all participated and } \\
\text { held responsibility for } \\
\text { ourselves and our project. }\end{array}$ \\
\hline & $\begin{array}{l}\text { Improve } \\
\text { efficiency } \\
(37,19.37 \%)\end{array}$ & $\begin{array}{l}\text { When they mention how teamwork is beneficial to } \\
\text { improve the efficiency (that is, do it faster and better) } \\
\text { in completing the projects, or to reduce the workload or } \\
\text { time required from individual members; when they talk } \\
\text { about time management; or, when they talk about } \\
\text { delegating, splitting, or dividing work among group } \\
\text { members helps improve efficiency. }\end{array}$ & $\begin{array}{l}\text { Working on a team helps } \\
\text { makes the process faster } \\
\text { and better. }\end{array}$ \\
\hline & $\begin{array}{l}\text { Strengths and } \\
\text { weaknesses } \\
(17,8.9 \%)\end{array}$ & $\begin{array}{l}\text { When they talk about the strengths and weaknesses of } \\
\text { group members in the project, such as what they good } \\
\text { at or not good at, how this could be a benefit or } \\
\text { disadvantage. Or indirectly, they talk about how } \\
\text { individual ability more fits certain work, implying the } \\
\text { utilization of one's strength. }\end{array}$ & $\begin{array}{l}\text { For me, I feel that it was } \\
\text { important because it } \\
\text { enabled me to know each } \\
\text { person's ability in order to } \\
\text { be fitted in the right place. }\end{array}$ \\
\hline \multirow{3}{*}{$\begin{array}{l}\text { Simulation to } \\
\text { real world } \\
(48.69 \%)\end{array}$} & $\begin{array}{l}\text { Different ideas or } \\
\text { perspectives } \\
(32,16.23 \%)\end{array}$ & $\begin{array}{l}\text { When they talk about different ideas, unique ideas, a } \\
\text { variety of ideas, more ideas, different styles, different } \\
\text { personalities, people from different cultures, regardless } \\
\text { of whether they deem it positive or negative. }\end{array}$ & $\begin{array}{l}\text { It also allows for multiple } \\
\text { points of view on } \\
\text { situations. }\end{array}$ \\
\hline & $\begin{array}{l}\text { Relevance to } \\
\text { real-world work } \\
(\mathbf{4 0}, \mathbf{2 0 . 9 \% )}\end{array}$ & $\begin{array}{l}\text { When students talk about the relevance of teamwork to } \\
\text { real-world project, including their future career. }\end{array}$ & $\begin{array}{l}\text { It is very important since } \\
\text { we will be working with } \\
\text { teams throughout our } \\
\text { career it's a good skill to } \\
\text { learn. }\end{array}$ \\
\hline & $\begin{array}{l}\text { Support each } \\
\text { other } \\
(22,11.5 \%)\end{array}$ & $\begin{array}{l}\text { When students talk about how they support each other } \\
\text { in the group, solve problems for other group members, } \\
\text { get help from other members, and how they trust each } \\
\text { other to do so. }\end{array}$ & $\begin{array}{l}\text { It is essential to work } \\
\text { together so that team } \\
\text { members may collaborate } \\
\text { and check each other's } \\
\text { work. }\end{array}$ \\
\hline \multicolumn{2}{|c|}{ Necessity $(73,38.22 \%)$} & $\begin{array}{l}\text { When they say the team is necessary for the project; } \\
\text { when they say the teamwork is critical or massively } \\
\text { important; when they say the project is insurmountable } \\
\text { or impossible for individuals; when they talk about } \\
\text { delegating, splitting, or dividing work among group } \\
\text { members is necessary for completing the project. }\end{array}$ & $\begin{array}{l}\text { There is no way everything } \\
\text { would have got } \\
\text { accomplished if this wasn't } \\
\text { a team project. }\end{array}$ \\
\hline \multicolumn{2}{|c|}{ Challenge $(35,18.32 \%)$} & $\begin{array}{l}\text { When students talk about experiences that indicate } \\
\text { negative feelings or when they narrate any difficulties } \\
\text { or challenges during teamwork. }\end{array}$ & $\begin{array}{l}\text { Communication was } \\
\text { critical, especially since the } \\
\text { full team was rarely } \\
\text { together due to conflicting } \\
\text { schedules. }\end{array}$ \\
\hline
\end{tabular}




\section{Discussion}

In this present study, we aim to investigate engineering students' perceptions of their teamwork experience in capstone design projects. To do so, we conducted a convergent mixed methods study to answer research questions on student perception on the role of teamwork, on the major themes in student understanding of teamwork, and on the tensions in the process of teamwork.

Findings indicated that students perceived teamwork as very valuable (rated 4.188 out of 5) to their learning experience in the course and relevant (rated 4.587 out of 5) to their future work as professional Chemical Engineers However, they did not report the desire to learn more about teamwork, with only one student out of 35 including teamwork skills when responding to the question of "What additional skills would you like to practice through in-class activities?" An in-depth analysis on student understanding of teamwork yielded four themes (Table 3), including team coordination (communication, individual responsibility, efficiency, strengths and weaknesses), simulation to the real world (different perspective, relevance to real world work, support each other), necessity, and challenges. While the findings indicate that students already had an appreciation for the critical aspects that contribute to the success of teamwork, further analysis on the challenges revealed further tensions and absences in the understanding of the collaborative processes. Those challenges, tensions, and lack of understanding indicate areas for further instructional support in developing teamwork competence in engineering students.

From the Venn Diagram (Figure 1), we can see that the Necessity category brought the most instances of challenge. That is, students found the sheer workload required a team to be completed but was still overwhelming and challenging even for a team of 7 people. This challenging project scope even for groups of 7 to 8 students has rippled its effect to other categories, such as efficiency as a team, open and active communication among team members, time and effort invested in the project, etc. That is, with the project scope and team size, they could find it difficult to communicate, or the investment in the project from team members differ, which cause problems in responsibility and accountability. Nevertheless, a large factor for this challenge was the nature of the capstone project, and the team size has effect on the team effectiveness [23].

From further exploration of the collaborative process, we can see that two categories of Responsibility and Different ideas or perspectives also overlap with Challenge. That is, tensions or challenges were reported as associated with individual responsibility and accountability, and individual differences in personality, ideas, perspectives, work styles, cultures, etc. Individual responsibility and accountability in teamwork has been one critical, often discussed problem. For research that studied factors that could either positively [14] or negatively [13] affect teamwork effectiveness, they often times included individual responsibility and accountability. Strategies were in place to counter the potential negative impact of irresponsible behaviors. Using traditional methods of meetings with the instructor and peer review did appear to address this challenge for these teams, but those methods have their own limitations, such as requiring too much faculty input. Therefore, we propose to use the framework of shared leadership from organizational psychology [24], [25], where the focus is on the within-group interaction without relying on external leaders or authorities, the leadership is distributed among team members who are authorized to equally exert influence on each other, and the individual member responsibility turns into shared and distributed leadership responsibility. This way, we could mitigate the tensions in holding individual members accountable in teams. 


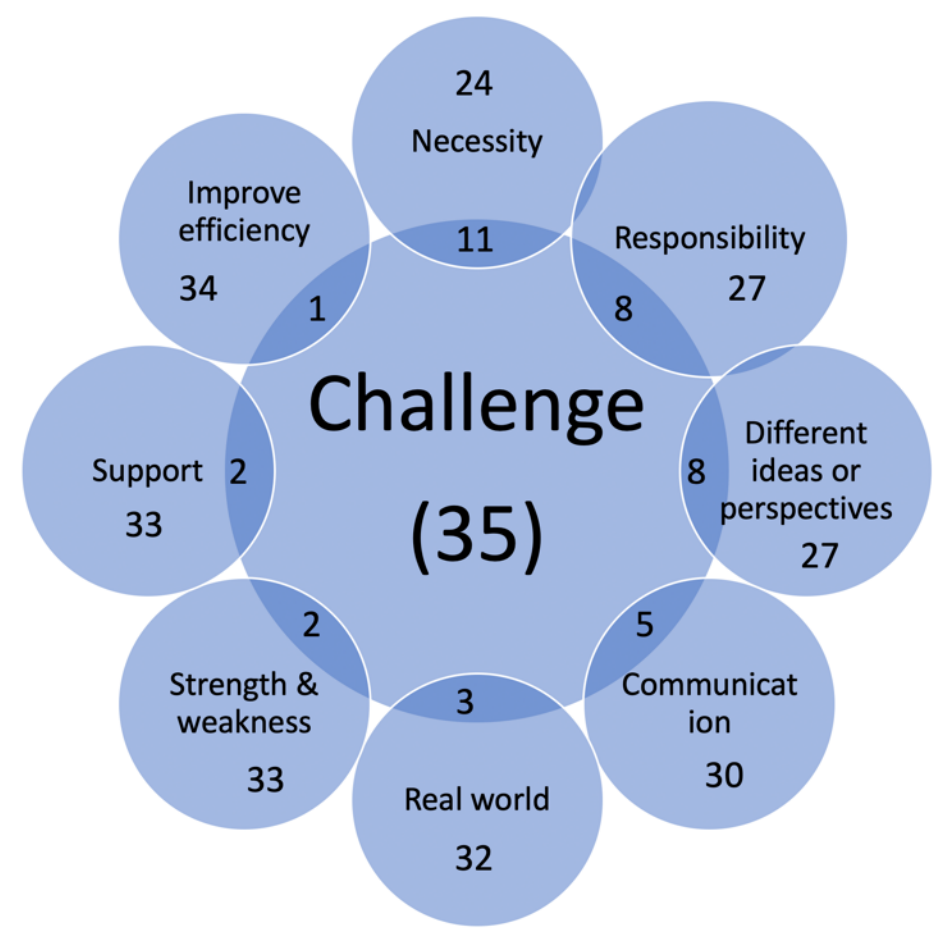

Figure 1. Challenges overlapping with other identified themes

Tensions brought by individual differences that contribute to the team diversity were also challenging to students working in teams. The new student outcome by ABET (2018) explicitly specifies that students need to be able to create and function in "collaborative and inclusive environment". While it is a desired outcome for students, as pointed out by Edmondson and Roloff [26], diversity could be an asset but not all teams are able to benefit from it. Edmondson and Roloff [26] analyzed three different types of team diversity and situations of their occurrences. They pointed out the critical role that open communication plays in overcoming adverse situations resulted from team diversity and further proposed using psychological safety to mediate the potential negative impacts as a result of individual differences. To help resolve this challenge seen by students, moving forward we recommend increasing faculty and students' awareness of psychological safety, which we believe could also help to address the other aspects on communication and support.

Literature from organization psychology have promoted psychological safety [2], [27], [28], the extent to which group members feel safe to take interpersonal risks, and how it is tied closely to group learning behavior. A high level of psychological safety in a group climate is positively related to interpersonal trust and respect where open communication and constructive critique is seen more often and there is more frequent help seeking and giving behaviors. To support for the psychological safety at the group level, we propose to provide instructional facilitation at the group level at two aspects. First, since contextual support where groups members share access to resources and information is helpful to team effectiveness [27], we propose to integrate the shared workspace, either physical or virtual, as part of the course routine. Students should also be encouraged to use the office hours with instructors or teaching assistants to make use of external help or resources for the benefit of their group project. Second, we propose to have at least one informal activity at the start of team formation to boost the interpersonal relationship and preferably a second activity for the same purpose sometime around 
the middle of the collaboration. These activities not only improve the interpersonal relationships but also provide opportunities for more effective communication among group members.

In interpreting the findings, we not only examined the tensions and challenges, but also absence in student perception. As we already pointed out earlier, while students perceived teamwork as critical, only one out of 35 students mentioned teamwork as one of additional skills they would like to practice through in-class activities. A further examination into their teamwork experiences as reported in responding to the question of "What is the importance of working on a team for this project?", we found another interesting lack of understanding, that even though some reported challenges, none of them talked about conflict resolution strategies (how they overcame these challenges). This is not surprising since it is common for team members to fear and avoid conflicts, especially for people from conflict-avoidant cultures [13], [29]. To address this issue, we propose to make conflict resolution part of regular activities and leadership responsibility to harness its benefits.

\section{Conclusion}

To better understand student perceptions and understanding of teamwork, we examined the student teamwork experience as reported in open-ended survey questions from two semesters over a year in a capstone course in chemical engineering. Findings from analyses of total 208 responses revealed that students deemed teamwork as very important, their experiences provided many opportunities for them to develop teamwork skills, but at the same time, their responses reported tensions and challenges in those experiences. We further discussed conflict resolution, which is a critical aspect of teamwork from the literature but not discussed by students. For students to develop teamwork skills, their recognition of its importance is a good start, and the tensions and absences have implications for researchers and practitioners in chemical engineering education to better support the development of teamwork skills. Further research is needed to design interventions as informed by the current study and evaluate the effectiveness of those interventions in supporting students' development of teamwork skills.

\section{Acknowledgement}

The authors would like to acknowledge the support from Leonhard Center for Enhancement of Engineering Education at College of Engineering in Penn State. 


\section{References}

[1] Ohland, M. W., Giurintano, D., Novoselich, B., Brackin, P., \& Sangelkar, S. (2015). Supporting capstone teams: Lessons from research on motivation. International Journal of Engineering Education, 31(6), 1748-1759.

[2] Edmondson, A. (1999). Psychological safety and learning behavior in work teams. Administrative science quarterly, 44(2), 350-383.

[3] Passow, H. J. (2012). Which ABET competencies do engineering graduates find most important in their work?. Journal of Engineering Education, 101(1), 95-118.

[4] ABET, “Criteria for accrediting engineering programs," 2018. [Online]. Available: http://www.abet.org/accreditation/accreditation-criteria/criteria-foraccreditingengineering- programs-2018-2019/.

[5] Loughry, M. L., Ohland, M. W., \& Woehr, D. J. (2014). Assessing teamwork skills for assurance of learning using CATME team tools. Journal of Marketing Education, 36(1), 5-19.

[6] Stahl, G., Koschmann, T., \& Suthers, D. (2006). Computer-supported collaborative learning: An historical perspective. In R. K. Sawyer (Ed.), Cambridge handbook of the learning sciences (pp. 409-426). Cambridge, UK: Cambridge University Press.

[7] Järvelä, S., \& Hadwin, A. F. (2013). New frontiers: Regulating learning in CSCL. Educational Psychologist, 48(1), 25-39.

[8] Michaelis, B. M., \& Bae, H. (2019). Optimizing Capstone Team Selection. In Proceedings of the $126^{\text {th }}$ Annual Conference \& Exposition of American Society for Engineering Education.

[9] Laguette, S. (2013, June). Team leadership on capstone design project teams. In ASEE Conference Proceedings Paper (Vol. 5904).

[10] Paretti, M. C., Pembridge, J. J., Brozina, C., \& Lutz, B. D. (2013). Mentoring team conflicts in capstone design: Problems and solutions. In Proceedings of the 2013 American Society for Engineering Education Annual Conference \& Exposition.

[11] Socha, D., Razmov, V., \& Davis, E. (2003). When conflict helps learning. In Proceedings of the 2003 American Society for Engineering Education Annual Conference \& Exposition.

[12] Ohland, M. W., Loughry, M. L., Woehr, D. J., Bullard, L. G., Felder, R. M., Finelli, C. J., ... \& Schmucker, D. G. (2012). The comprehensive assessment of team member effectiveness: Development of a behaviorally anchored rating scale for self-and peer evaluation. Academy of Management Learning \& Education, 11(4), 609-630.

[13] Lencioni, P. (2002). The Five Dysfunctions of a Team. Jossey-Bass.

[14] Loughry, M. L., Ohland, M. W., \& Moore, D. (2007). Development of a theory-based assessment of team member effectiveness. Educational and psychological measurement, 67(3), 505-524.

[15] Borrego, M., Karlin, J., McNair, L. D., \& Beddoes, K. (2013). Team effectiveness theory from industrial and organizational psychology applied to engineering student project teams: A research review. Journal of Engineering Education, 102(4), 472-512.

[16] Beigpourian, B., Ferguson, D. M., Berry, F. C., Ohland, M. W., \& Wei, S. (2019). Using CATME to document and improve the effectiveness of teamwork in capstone courses. In 2019 ASEE Annual Conference and Exposition Proceedings.

[17] Lingard, R., \& Barkataki, S. (2011, October). Teaching teamwork in engineering and computer science. In 2011 Frontiers in Education Conference (FIE) (pp. F1C-1). IEEE. 
[18] Creswell, J. W., \& Plano Clark, V. L. (2018). Designing and conducting mixed methods research ( $3^{\text {rd }}$ ed.). Thousand Oaks, California: SAGE.

[19] Miles, M. B., Huberman, A. M., \& Saldaña, J. (2014). Qualitative data analysis: A methods sourcebook ( $3^{\text {rd }}$ ed.). Thousand Oaks, Califorinia: SAGE Publications, Inc.

[20] Tashakkori, A., \& Creswell, J. W. (2007). The new era of mixed methods. Journal of Mixed Methods Research, 1, 3-7.

[21] Fetters, M. D., Curry, L. A., \& Creswell, J. W. (2013). Achieving integration in mixed methods designs principles and practices. Health Services Research, 48, 2134-2156.

[22] Camiel, L. D., Kostka-Rokosz, M., Tataronis, G., \& Goldman, J. (2017). Performance and Perceptions of Student Teams Created and Stratified Based on Academic Abilities. American journal of pharmaceutical education, 81(3), 47.

[23] Baykasoglu, A., Dereli, T., \& Das, S. (2007). Project team selection using fuzzy optimization approach. Cybernetics and Systems: An International Journal, 38(2), 155185.

[24] D’Innocenzo, L., Mathieu, J. E., \& Kukenberger, M. R. (2016). A meta-analysis of different forms of shared leadership-team performance relations. Journal of Management, 42(7), 1964-1991.

[25] Mathieu, J. E., Kukenberger, M. R., D'innocenzo, L., \& Reilly, G. (2015). Modeling reciprocal team cohesion-performance relationships, as impacted by shared leadership and members' competence. Journal of Applied Psychology, 100(3), 713.

[26] Edmondson, A. C., \& Roloff, K. S. (2008). Overcoming barriers to collaboration: Psychological safety and learning in diverse teams. In Team effectiveness in complex organizations (pp. 217-242). Routledge.

[27] Edmondson, A. C., Kramer, R. M., \& Cook, K. S. (2004). Psychological safety, trust, and learning in organizations: A group-level lens. Trust and distrust in organizations: Dilemmas and approaches, 12, 239-272.

[28] Edmondson, A. C., \& Lei, Z. (2014). Psychological safety: The history, renaissance, and future of an interpersonal construct. Annual Review of Organizational Psychology and Organizational Behavior, 1(1), 23-43.

[29] Burke, C. S., Priest, H. A., Wooten II, S. R., DiazGranados, D., \& Salas, E. (2008). Understanding the cognitive processes in adaptive multicultural teams: A framework. In Team Effectiveness in Complex Organizations (pp. 243-274). Routledge. 
Appendix

Table 1. Survey items used in 2017 fall and 2018 spring semesters

\begin{tabular}{ll}
\hline Overall & 1. My overall rating of the course is good. \\
experience & 2. The pace of the class is appropriate for my learning. \\
3. The 50-minute Monday lecture is helpful. \\
4. The 2-hour session is helpful. \\
5. The in-class assignments are useful. \\
6. The out-of-class readings are informative. \\
7. I review the readings before lecture each week. \\
8. Meeting with industry mentors is helpful. \\
9. The role of the industry process mentor in the capstone project is clear. \\
10. The grading for the course is clear. \\
11. The graduate TAs in this course help with my learning. \\
12. The undergraduate TIs in this course help with my learning. \\
13. The stage/gate setup of the project is useful. \\
14. I know the scope and intended audience of Status Memos. \\
15. I know the scope and intended audience of the Gate Assignments. \\
16. I know the scope and intended audience of the final Design Report. \\
17. I feel comfortable using the software needed in my capstone project. \\
18. The software needed in my capstone project is useful/important. \\
19. Working on the capstone project as a team is a valuable experience.
\end{tabular}

Skills relevant 1. Writing

to future 2. Teamwork

career 3. Using Modeling Software (e.g. Aspen+)

4. Solving an Under Defined Problem

5. Designing Equipment

6. Economic Evaluation

How helpful 1. Review/Pretest

course aspects 2. Team status and gate meetings with mentors

are in 3. Teammate evaluations

completing 4. Writing Assignments (e.g. status memos, gate documents, and design project report)

5. Using Modeling Software (e.g. Aspen+)

6. In-class assignments

7. Readings

8. Meetings/office hours with the professor

9. Office hours with TAs/TIs

Time Review of material (Pretest)

expectations Stage 1: Generate Options

for sections of Stage 2: Reduce Options 
the class

Stage 3: Model Process

Stage 4: Design Equipment

Stage 5: Economic Evaluation

Open-ended questions (2017 Fall)
1. What additional skills would you like to practice through in-class activities?

2. What is the importance of working on a team for this project?

3. If you were the instructor for this course, how would you improve the content delivery?

4. Please use the space below to provide any additional feedback about the course.

Open-ended questions

1. What aret

2. What is the importance of working on a team for this project?

(2018 Spring) 3. What type of job/career do you plan to do after graduation?

4. If you were the instructor for this course, how would you improve the content delivery?

5. Please use the space below to provide any additional feedback about the course. 